\title{
Personal Social Support and Non-Support in Career Aspirations towards Senior Management amongst Women in Middle Management: Multiple Dimensions and Implications on Measurement
}

\author{
Ariyamuni Priyanthi Silva ${ }^{1}$, Aminah Ahmad ${ }^{1}$, Zoharah $\operatorname{Omar}^{1}$ \& Roziah Mohd Rasdi ${ }^{1}$ \\ ${ }^{1}$ Department of Professional Development and Continuing Studies, Faculty of Educational Studies, University \\ Putra Malaysia, Selangor, Malaysia \\ Correspondence: Ariyamuni Priyanthi Silva, Department of Professional Development and Continuing Studies, \\ Faculty of Educational Studies, University Putra Malaysia, Selangor, Malaysia. Tel: 60-1-7317-9560. E-mail: \\ priyanthi.silva11@gmail.com
}

Received: April 23, 2012 Accepted: May 30, 2012 Online Published: August 30, 2012

doi:10.5539/ass.v8n11p205

URL: http://dx.doi.org/10.5539/ass.v8n11p205

\begin{abstract}
Women middle managers aspiring for senior management execute their career choices in a unique career context. They experience the influence of personal social support and non-support in executing their aspirations towards senior management. Yet, it is observed that measures available to capture personal social support and non-support of this cohort of careerist are not adequately comprehensive. It was felt that there is a considerable space to develop a measure on personal social support and non-support as a contextual factor that affects career choice of women in middle management aspiring for senior management. This paper aims to highlight possible multiple dimensions of personal social support and non-support that affect career aspirations towards senior management amongst women in middle management. Concurrently, it offers some recommendations to develop a measure to capture aforementioned phenomena. To fulfill above aims, a targeted literature review on main areas under discussion was carried out in leading scientific databases such as EBSCOhost, JSTOR, ProQuest, Science Direct, and SpingerLink with the use of key words: women, career choice, aspirations, management, leadership, social support, significant others, and measurement. It is believed that development of a measure to capture the influence of personal social support and non-support in career aspirations towards senior management amongst women in middle management might contribute to enhance the quality of research conducted in this area and intervention programmes taken up to support female senior management aspirants.
\end{abstract}

Keywords: women managers, career aspirations, personal social support, personal social-non support

\section{Introduction}

Female underrepresentation in senior management has been proposed as a prevailing global experience (International Labour Organization, 2010; Carter \& Silva, 2010). Highly masculinized and feminized occupations are termed as extreme-end gender dominant careers (Reyes, Kobus \& Gillock, 1999) based on observations on gender distribution of a particular vocation. In that vein of understanding, senior management continues to be a highly masculinized level in management occupation. Some authors have reported that aspiration levels of females to enter corporate business are far less than that of males (Reyes etal., 1999). Literature provides ample of critical viewpoints that this low entrance of women in to senior management is caused by various contextual career factors (Lawrence,Poole, \& Diener, 2003;Omar \& Davidson, 2001; Betz \& Fitzgerald, 1987). Personal social support and non-support are among such contextual factors (Levine, Lin, Kern, Wright, \&Carrese, 2011;Lent, Brown, \& Hackett, 2000;1994; Betz \&Fitzgerald, 1987).

Career choice development in non-traditional careers for women has been long debated to be very much influenced by contextual reinforcements existing in her proximal environment. Here, non-traditional careers refer to careers that only a minority of women has selected to pursue throughout the history. Generally, as a source of support, positive reinforcements (e.g. social encouragement) transmitted by parents, partners/spouses, teachers, friends, co-workers, etc. have been pointed as a vital ingredient for successful choice of and persistence in careers (Lent et al., 2001; Lent, et al, 2000;Lent, et al, 1994) and as a buffering factor in the face of other 
career barriers (Lease, 2006). As an example, the influence of family members in establishing career choice goals is thoroughly discussed in career literature (Sellers, \& Hunter, 2005; Flores \& O’Brien 2002; Ferry, Fouad, \& Smith, 2000;Byars \& Hackett, 1998). Stated differently, dearth of such support resources can be highly detrimental if an individual is pursuing a non-traditional career within a mesh of other external constraints. To that extent, personal social support may act as a contextual career barrier that is generally termed as disapproval of significant others in career literature (Lent et al., 2000).

Betz and Fitzerald (1987) advocates Fyre's (1984) speculation that one of the important dimensions of self-perceptions of success held by women is the evaluations of significant others (e.g. family, co-workers, peers).Therefore, in their model, perceived encouragement has been assigned a significant role in determining the career choice realism. On the other hand, since women's career decisions are relational in nature (Mainiero \& Sullivan, 2005), they might pay attention to impact of their career choices on maintaining and enhancing valued relationships. For instance, female employees tend to be seeking for more spousal agreement in case of work interfering with family (McElwain, Korabic, \& Rosin, 2005). It has been found that female leaders tend to consume support resources from multiple sources like spouses, parents and other family members in their career pursuits (Beaty \& Pankake, 2001; Ballentine, 2000). Therefore, social support for career choice development stands a vital role in female's career development.

The main purpose of this paper is to elaborate the influence of personal social support and non-support in shaping career aspirations of women in middle management towards senior management as a construct with multiple dimensions. Secondly, it attempts to make recommendations in relation to adapt or innovate measurement instruments to capture the comprehensive influence of personal social support and non-support towards career aspirations for senior management. In identifying the gap in literature and developing suggestions, a targeted literature review on main areas under discussion was carried out in leading scientific databases such as EBSCOhost, JSTOR, ProQuest, Science Direct, and SpingerLink with the use of key words: women, career choice, aspirations, middle management, leadership, social support, significant others , and measurement. It is believed that the introduction of a measurement, as proposed by this paper, in the field of career development is timely and would contributes to the enhancement of the utility value of research in this area.

\section{Defining Personal Social Support and Non-support}

This paper focuses on two critical aspects of social support namely, personal social support and personal social non-support in relation to career aspirations of female middle managers.

\subsection{Personal Social Support}

Some prevailing definitions on social support can be utilized to define personal social support for women in middle management aspiring for senior management. According to Lent and Brown (2006), supports are 'facilitative influences that people anticipate that will accompany their goal pursuit' (P. 18). In some occasions, they have employed the term 'social support' (Lent et al., 2007; Lent et al., 2001) to convey this encouraging assistance received from proximal social members. In stress research, it has been identified as the overall configuration of relationships and the stream of resources circulated by such relationships (Greenhaus \& Parasuraman, 1994) that facilitates dealing with stress.

Concurrently, some additional factors that characterizes social support also can be considered in the process of defining personal social support for aspiring female middle managers. The social support is dependent on the characteristics of networks people establish with others around them. In fact, if the support senders are related to non-work domains it is identified as 'personal social support' (Marcinkus, Whelan-Berry \& Gordon, 2007). These senders include the spouse or partner, parents, siblings, children, extended family, and friends (Marcinkuset al., 2007; Beaty \& Pankake, 2001).

Generally, social support is subject to personal assessment of the receiver whether it is instrumental supportdirect contribution to solve a problem or expressive support - providing the context to manage the emotional aspects of a problematic situation or ' positive affective experience' that includes caring, sympathetic listening and empathy (Shaffer et al., 2005; House \& Kahn, 1985).

At this point, it should be made clear that amongst many other sources of social support, the focus of this paper is on the personal sources of support and non-support in relation to career choice behaviour. Hence, the definition proposed for personal social support would be, any instrumental or emotional assistance women in middle management gain from their personal sources of support in non-work domain that will facilitate their career aspirations for senior management. 


\subsection{Personal Social Non-support}

In identifying the nature of personal social non-support, there are few clarifications to be provided. In total agreement with Betz (1989), Lent and associates (2000) delineated that the absence of support or 'null environments' does not indicate that social support is a contextual career barrier per se. Instead, if there is an expressed disagreement on the career choice that comes into effect, in a form of disapproval, it can be considered as a contextual career barrier. To make it more clear, social support becomes a contextual barrier only when it can be identified as a conscious disapproval towards a career choice by anticipated sources of support. As such, when they operationalized contextual career support as a contextual career barrier, their aim was to capture discouraging reactions received or to be received from significant others or felt pressure received or to be received from significant others or negative reactions of significant others in the career choice process (Lent et al., 2008; Lent et al., 2003a).

As an important aspect in relation to conceptual clarity, they do not deny the possibility of the support and barrier dimensions of social support to be inversely related as independent variables or to be placed on a negative- positive continuum (Lent et al., 2003a; Lent et al., 2001; Lent et al., 2000, P.42). Therefore, it can be seen that both personal social support and non-support are mirroring concepts that can be measured independently. As Lent, Brown, and Hackett (2000) suggested, it should be measured together in the same research context to capture the complete influence of the proximal context on career choice behaviour.

For the purpose of this paper, personal social non-support is defined as any instrumental or emotional resistance women in middle management experience from their anticipated personal sources of support in non-work domain that will discourage their career aspirations for senior management.

This paper would address both personal social-support and non-support in giving its suggestions following the proposal of Lent and colleagues (2000).

\section{The Relationship of Personal Social Support and Non-support with Career Aspirations}

The role of personal social support and non-support in career choice development are elaborated in following sections with the use of few theoretical underpinnings and empirical findings. These elaborations might be helpful to establish possible influence of personal social support and non-support on career aspirations of female middle managers.

\subsection{Theoretical Underpinnings}

An individual's surrounding of existence is viewed by Bronfrenbrenner (1979) as an ecological system which is comprised of an array of nested systems. Bronfenbrenner (1977) clarifies that human behaviour is subject to the influence of four ecological structures namely, microsystems, mesosytems, exosystems, and macro systems (as cited in Vondrasec, Lerner, \& Schulenberg, 1986). Microsystem is comprised of interactions of the individual within the inner most context such as home, school and the support senders like family and friends (Lent et al, 2000; Fouad \& Bingham, 1995). This approach has been embraced by contexualists in career development theories (Lent et al, 2000; Vondrasec, Lerner, \& Schulenberg, 1986). In line with this contextual view point, Cook, Heppner, and O'Brien (2002) presented an ecological model of the career development, which conceptualizes career behaviour in a backdrop of individual, interpersonal, and socio-cultural ecological layers.

Bronfrenbrenner (1979) claimes that in the center of ecological system there contains the dyad of two partners which can be identified as the family system. As per the family systems theory, attitudes and experiences of family members have a sway in attitudes and experiences of the rest of the members (Streich, Casper, \& Salvaggio, 2008). To this extent, the mutual influence of a couple on vital dimensions of life such as work and family is inevitable (Hammer, Bauer, \& Grandey, 2003) and it is important how the two members, for instance in a dual career family, agree on their perceptions (Streichet al.,2008) regarding those dimensions.

Simplifying nested systems perspective, Lent et al., (2000) elaborated that the context of the person can be disintegrated into different layers that can be portrayed as concentric circles. The family, friends and such immediate factors that affect their career development belong to immediate, proximal context within their Social Cognitive Career Theory (SCCT) framework for career choice development. They insist that the immediate proximal context channels information about the career barriers in larger societal contextual layer, creates the background for coping with them, and buffers the career choice process.

Bussey and Bandura (1999) clarifies within a social cognitive learning framework that when an individual is not complying with assigned societal norms they are sanctioned in numerous ways. In anticipation of such resistances, individuals may avoid such pursuits that are not approved by influencing others. Rather, there is a 
tendency to pursue career paths encouraged by others. This condition can be expected to come into clear existence when a person is choosing between gendered vocations.

In sum, these theories and models cited above highlights the importance of social support and non-support in shaping career choices. In the same line of argument, it can be proposed that as a career choice variant, career aspirations may also be characterized by personal social support and non-support experienced by female middle managers.

\subsection{Empirical Evidence}

The influence of personal social support and non-support can be explained using some empirical investigations. In assessing three dimensions of motivation: aspiration, mastery and career achievement motivation, Farmer (1985) found that parental support, teacher support and other supportive attitudes would predict career aspiration. Otto (2000) was interested to know the sway of parents in career development of young men and women. They collected survey data from 362 high school juniors that consisted of both majority and minority groups. The results indicate that the parents are very much influential in approving and facilitating career aspiration decisions. Young and McLeod (2001) accessed twenty female educational administrators and educational administration students to understand the factors that determine their decision to become educational administrators. They found that endorsement and support contribute to the choice of administration career paths. They discussed that the disapproval or lack of support were found to bear negative effects on career choice.

Flores and O'Brien (2002) employed SCCT career choice model to examine the influence of contextual and social cognitive variables on career aspiration, career choice prestige, and traditionality of 364 Mexican American adolescent women. They found that parental support was significantly and positively related to career aspirations. They asserted that Mexican American adolescent women may choose highly prestigious careers depending on the approval of others, their family obligations, and parental support which can off-set negative effects of other career barriers. Another study conducted by Lent et al. (2005) revealed that social barriers significantly explained the engineer major choice of 487 male and female students in two university types.

The Hudson leadership survey (McGowan, 2007) encompassed 200 female business professionals in USA. The managers in middle management revealed that the support rendered by their husbands/life partners is critical in advancing their career. About $77 \%$ of the overall female middle managers covered in the study were aspiring for senior management. Successful seven senior women in the Chinese IT industry were interviewed by Xian and Woodhams (2008) to investigate their career experiences, employing personal narrative method. They found that husband's support was an enabling mechanism to sustain their non-traditional career goals. Lent et al., (2008) employed SCCT to understand the predictive capability of social support and social barriers, amongst three other variables, towards career interests and choice development of students in the computing disciplines. The sample represented 1208 university male and female students in different educational levels attached to two types of universities. Social barriers, which included felt pressure from significant others significantly accounted for career choice. Empirical investigations compiled so far indicate the influence of personal social support and non-support in determining career aspirations.

\section{Women Middle Managers Aspiring for Senior Management}

It is important to understand some contextual aspects of women middle managers at this point. Female middle managers come into close proximity of senior management career dynamics and generally, are in the selection pool for senior management. The average age of women in middle management has been reported to be more than 33 years in most of the research settings (Wentling, 2003; 1996; Hornsby, Kuratko, \& Zahra ,2002). The age range between 35-50 is identified as midlife stage in terms of life stage (Levinson, 1996; Levinson, Darrow, Klien, Levinson, Mckee, 1978). Nonetheless, individual's perceptions on contextual influences, for instance contextual career barrier perceptions, might vary across life stages (Murtagh, Lopes, \& Lyons, 2007; Russell \& Rush, 1987). Women in mid-life are confronted with simultaneous pressure which occurred due to high expectations of performance in mid-career and increasing family responsibilities in mid-life (Marcinkus, Whelan-Berry \& Gordon, 2006). Child care, elderly care, spouses, managing marriage life, managing between roles, and keeping up with competency requirements are the key challenges faced by mid-life working women (Wallen 2002; Whelan-Berry and Gordon, 2000). Additionally, they tend to be renewing their life priorities in this stage (Gordan \& Whelan-Berry, 2004).

How individuals exchange social support is dependent on their specific life stage i.e. young adult to old and spouse, friends, colleagues, and neighbours are the main sources of personal social support in mid-life (Schulz \& Rau, 1985). Marcinkus and colleagues (2006) contested that working women in midlife, particularly, are in need of drawing upon social support available in both work and non-work domains very much. 


\section{Multiple Dimensions of Personal Social Support and Non-support for Women in Middle Management Aspiring for Senior Management}

A literature review conducted for an intersection of women in management and career choice behaviour revealed that personal social support and non-support in their career aspirations might be constructed of multiple dimensions and sub-dimensions (Ogden, 2006;Gordan \& Whelan-Berry, 2004; Glick \& Hilt, 2000; Lent et al., 2000). Therefore, below section is dedicated to discuss those dimensions and sub-dimensions in brief.

\subsection{Attitudes of Support Senders on Women's Role}

The disapproval towards women pursuing a non-traditional career might be expressed in subtle manners in the form of strongly held attitudes by support senders on various aspects of her role in family and work domains. The assigned sex-typical roles for women in society have been long concentrated on homemaking while the men's have been breadwinning (Wharton, 2006; Eagly, Wood, \& Diekman, 2000). Support senders attitude could be such that the conventional role assignments has to be sustained for the wellbeing of the family and women's work should not interfere with family. In case of interference they also might expect that women should prioritize family (McElwainet al., 2005) or the husband's career (Deutsch, Kokot, \& Binder, 2007; Larwood \& Gutek, 1987; Markham \& Pleck, 1986). That type of attitude might operate as disapproval for a non-traditional career pursuit as such careers generally demand more focus on work related activities. On the other hand, if support senders hold much flexible egalitarian attitudes there is more potential to translate those attitudes into career choice supportive behaviours.

Men in society have been entrusted with more power to control important resources and dependency of women upon them is expected (Glick \& Hilt, 2000). As such, men had been considered as the powerful and protective agent of women. When a woman pursues a high prestige position, the support senders might hold an attitude that this pursuit is challenging husband's status in the family (Connell, 2002; Linehan \& Walsh, 1999). That attitude might have higher tendency to convert to explicit disapproval for ambitious career goals. In contrast, if the beliefs of support senders are not male patriarchal in nature, there is more tendency to offer career support irrespective of the shifting status of women in the family.

On the other hand, corporate management is a cross-sextyped occupation for a woman (Schein, 2001) in relation to widely held stereotypical beliefs and empowers her with 'exercising public power', which is considered as unfeminine (Xian \& Woodhams, 2008, P. 421). If the support senders hold similar stereotypical attitudes, there would be higher tendency to disapprove a career goal towards senior management. Therefore, the lesser support senders are restrained by such limiting attitudes the higher will be the probability to extend support for goal pursuit of a women manager towards senior management.

Therefore, attitudes of support senders about women's role may be reflecting three sub- dimensions: women's role in the family, women's status in the family, and appropriate careers for women.

\subsection{Work-family Facilitation Behaviours}

It has been pointed out in literature that career performance of women is contingent upon how they manage the conflict between work and family. For instance, in case women find that it is difficult to manage the work and family commitments successfully, they tend to sacrifice their career to cater for family roles at a higher rate compared to men (Guillaume \& Pochic, 2009; Hooks, 1998). Further, as Perna (2001) found, parental and marital responsibilities restrict career aspirations of females in higher education.

In many research it has been discussed that women devote more time on domestic activities than men in dual earner careers (Gerstel \& Sakisian, 2006) even in contemporary societies. As a result, if spousal support is sufficiently rendered to share domestic labour and to fulfill expressive needs to buffer work-family conflict (WFC) (Kim \& Ling, 2001; Grzywacz \& Marks, 2000), it will be a positive reinforcement to lead a progressive career (Gordan \& Whelan-Berry, 2004). However, if such support is not granted to manage WFC, it can be considered as a mean of disapproval towards an even more challenging career option that probably will further intensify WFC (Lo, 2003). If a woman manager does not receive required support currently, it implies that she will neither receive it in future and as a result it is likely that her WFC might be intensified. Support senders may attribute a current WFC experienced by a women manager to her non-traditional career aspirations that in turn can be considered as disapproval of further career progression.

According to cross-over effect analysis (Westman, 2005), the higher level of work demands in spouses job roles may impose a restriction of career development of women. Because, as the partners' ability to accommodate domestic needs decreases, a females' anticipation to access more challenging career options might be restricted. This scenario might contribute to pay more attention on prime role assignment as a homemaker or compel her to 
scale back (Bowes, 2005). Anderson-Gough, Grey, and Robson (2005) found that one of the informants clearly indicate that his focus on career could be maintained because of delegation of familial responsibilities to his wife. Hence, the spousal work-family conflict might spill over to female career development as a natural restriction or as an expressed disapproval. If it does not lead to compromises on female's career, but rather if spouse facilitates to maintain female's career goals it can be treated as a form of personal social support rendered for a progressive career.

Female career has been much debated to be affected by interruptions due to child bearing and rearing (Deedar-Ali-Khawaja, \& Khan, 2010; Rönsen\&Sundström, 1996). Family friendly policies have contributed to inculcate a conducive environment to minimize adverse effects of WFC (Sutton \& Noe, 2005; Dulk, 2005). If the partner is not willing to utilize such facilities, a female partner might have to compromise her optimal career options. For instance, whether the male partner is not willing to consume paternity leave granted will lead to career compromising decisions on female's side. This tendency will operate as a disapproval of continuing career aspirations towards senior management that requires clear focus and investment of resources.

Therefore, Work-family facilitation behaviours may encompass three sub-dimensions: sharing domestic roles, managing crossover effect, and partners' consumption of family friendly facilities.

\subsection{Career Decision Making Support}

When an aspirant is aspiring towards a non-traditional career the encouragement offered by support senders will raise the self-confidence of the aspirant to maintain their aspirations and mitigate career barriers (Lent et al., 2000). This encouragement may be provided to reduce the guilt feelings associated with trade-offs (e.g identity dilemma between motherhood and professional) (Linehan \& Walsh, 1999), by extending instrumental and emotional support to manage other career barriers, by granting the freedom to set optimal career goals that can minimize the ability- achievement gap, and by facilitating the career decision making process (Gordan \& Whelan-Berry, 2004). If the support senders withdraw themselves from offering such support, it can be considered as a form of disapproval.

Therefore, career decision making support as a dimension of personal social support and non-support may carry two sub-dimensions: career choice efficacy building behaviour and instrumental support required for career choice decision making.

\subsection{Support on Career Development Activities}

A careerist has to invest in career development activities that make the career progression a reality. For instance, networking with useful individuals has been pointed out as one of the critical determinants of managerial career success (Forret \& Dougherty, 2004; Davidson \& Cooper, 1992). Yet, there is resource (e.g. time) and cultural limitations that hinder women investing in this type of activities (Omar \& Davidson, 2001). The support senders can facilitate women managers' career choice by creating opportunities and space for such activities. If they discourage such efforts, it can be considered as a form of disapproval.

On the other hand, limited career mobility of women has been pointed out as a restraining factor for woman assuming challenging work assignments (Ogden, 2006) in preparation of senior management. Women are found to be more sensitive to career needs of their husbands rather than vice versa and tend to adopt their career involvement according to the attitudes of the husband (Cleveland, Stockdale, \& Murphy, 2000). If there is an unwillingness of male partner to mobile along with a female career moves or to adjust effectively, it can be identified as a form of disapproval. It should be noted that senior management positions require former cross-functional, cross- organizational, or international exposure (Linehan \& Walsh, 1999).

Therefore, the dimension of support on career development activities may contain three sub-dimensions: cultural freedom, resource allocation and relocation flexibility.

In conclusion, the dimensions of personal social support and non-support of women middle managers to aspire towards senior management so far identified can be summarized in a structure as in Figure 1.

\section{Measuring Personal Social Support and Non-support for Career Choice}

Any evolution of a concept should be converted in to a measurement to yield its optimal utility in an empirical setting. Because, "many areas of science measure things derived from theory. Until subatomic particle is confirmed through measurement, it is merely a theoretical construct" (DeVellis, 2003, p.6). Therefore, if the experience of personal social support and non-support for women middle managers aspiring senior management could be different from other cohorts, the sequential question is whether there is adequate vocational 
measurement instruments to capture this phenomena. The utility of personal social support and non-support as a construct is materialized in research only if the concurrent measurements are constructed.

Two of the most prominent instruments recently utilized to measure personal social support and non-support in career choice behaviour are Career Barriers Inventory developed by Swanson and colleagues (Swanson \& Woitke, 1997; Swanson \& Daniels, 1996;Swanson \& Tokar, 1991a; 1991b) and contextual career support/barrier instrument invented by Lent and associates (2008; 2005; 2003a; 2003b;2001). There are common characteristics that can be observed in the two instruments. First, they captured domain specific data from student samples. Second, they are vehemently validated with student samples (Lent et al., 2008; 2005; 2003a; 2003b;2001; Swanson \& Woitke, 1997; Swanson \& Daniels, 1996;Swanson \& Tokar, 1991a; 1991b). Third, the instruments are adapted to match contexts of student samples and their career choice dynamics. Finally, they have not addressed many dimensions and sub-dimensions of personal social support and non-support in relation to career choice of women middle managers elaborated in the previous section. Therefore, if a researcher is interested to capture multiple dimensions of personal social support and non-support for female middle managers, those instruments cannot be utilized and they have to be significantly adapted.

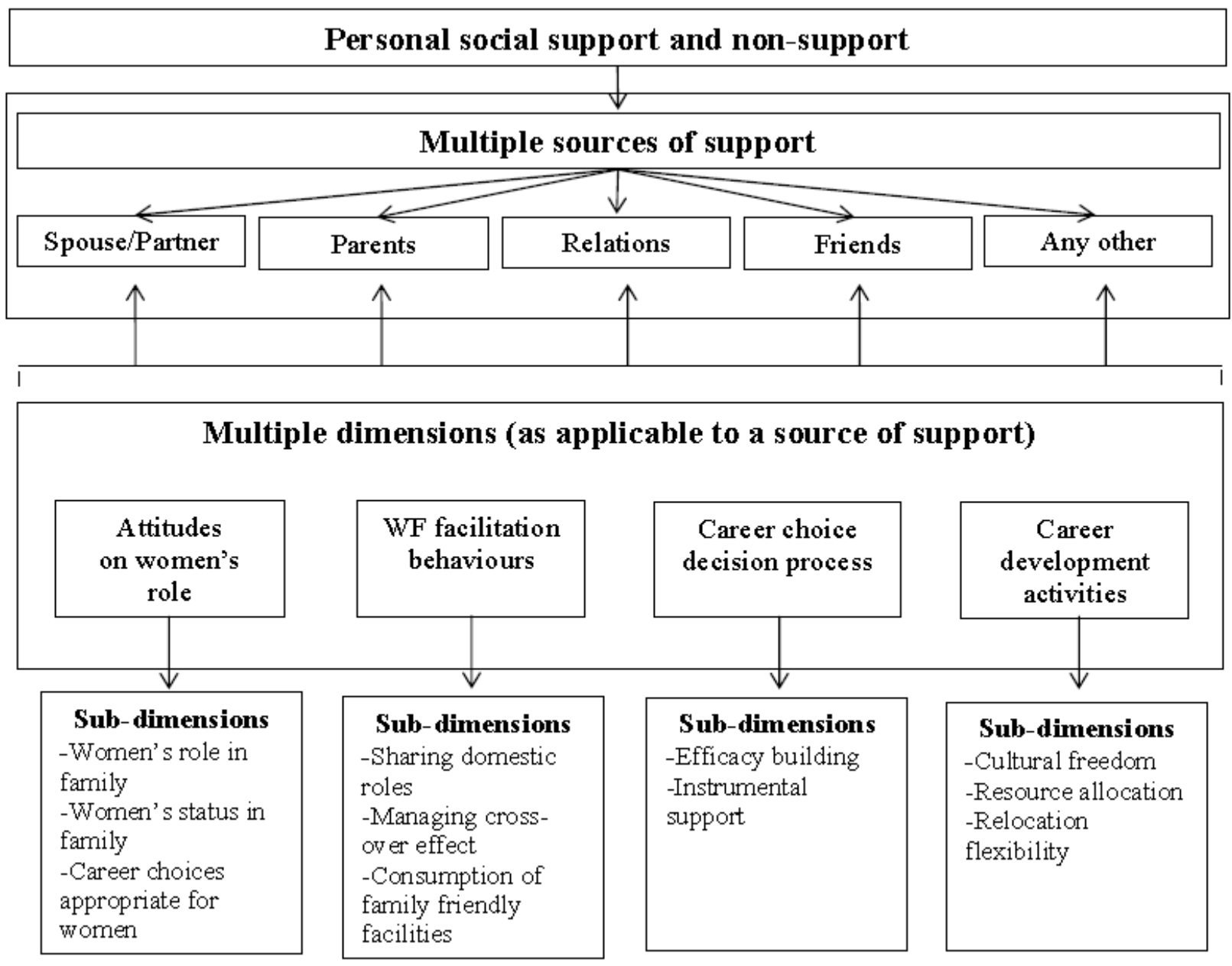

Figure 1. A structure of multiple sources, multiple dimensions and multiple sub-dimensions of personal social support and non-support for women in middle management aspiring for senior management

On a different note, a cursory review in Mental Measurement Year Book (Plake, Impara, \& Spies, 2003) revealed that there is no closely applicable measurement to capture these phenomena under consideration. In some circumstances, for instance Rowe (2003) in developing the work potential profile for individuals seeking employment, attempted to incorporate social resources as a dimension. However, it is very much doubted that whether this measurement is broad enough to capture personal social support and non-support experienced by women in middle management aspiring for senior management. Nevertheless, in its four volumes of Comprehensive Handbook of Psychological Assessment (Goldstein, Beers, \& Hersen, 2004; Hisenroth, Segal, \& Hersen, 2004; Haynes, Heiby, \& Hersen, 2004; Thomas, Hersen, 2004) there was no measurement instrument 
detected that can cater for this measurement requirement sufficiently. Therefore, it can be pointed out that there is a considerable space for developing a measure to capture dimensions of personal social support and non-support for women in middle management.

\section{Recommendations for Developing a Measure on Personal Social Support and Non-support for Women Middle Managers Aspiring for Senior Management}

A few suggestions can be made to develop a measure on personal social support and non-support for women middle managers aspiring for senior management.

First, is the need to contextualize the measure in line with the domain of interest. A measurement that attempts to capture any social cognitive construct should secure domain specificity as an important characteristic in social research (Lent \& Brown, 2006). Here, one has to contextualize measures, to draw a comprehensive domain sample in constructing the measure (Lent \& Brown, 2006). Lent and Brown (2006) suggests to sufficiently represent the domain of interest, collaborating knowledge drawn from theoretical and empirical literature, interviewing domain participants, open-ended surveys directed at them, direct observation of the activities in the domain, or creating a position description of the ideal features if someone performs a specific role in a particular domain are some avenues to consider to reach this objective (Lent \& Brown, 2006). In their scale development they adapted a pre-developed measurement specifying the context for instance, for students' career choice in engineering majors (Lent et al., 2007; Lent et al., 2005; Lent et al., 2003b), computing (Lent et al., 2008; Lent et al., 2005) and math and science subject streams selection (Lent et al., 2001).

Second, is to take multiple approaches grounded on literature review to capture multiple dimensions of personal social support and non-support. The process followed by Lent and associates in deriving their career social support and non-support can be cited as a case study. They reviewed prevailing literature in the general area of social support that led to find some existing measures. They found that prevailed measures were of lesser applicability in the selected domain (e.g. career choice and contextual support and barriers). Therefore, they opted to initiate a qualitative study in the specific domain and then did a content analysis that contributed to construct the quantitative measurement (Lent \& Brown, 2006). Subsequently, Lent and associates (2003a) adapted Lent and associate's (2002) interview outcomes on influence of significant others as both support and barriers. This included types of positive and negative reactions that one might receive from important others in one's life (supports and barriers) for different types of career choices (e.g. agricultural).

Third, is thorough verification of the measure in different research settings. Lent and colleagues (2008; 2005; 2003a; 2003b), as explained in above paragraphs, consecutively adapted their measures in various research settings for student samples, further validating and verifying the measurement. A similar process can be suggested to construct a comprehensive measure on personal social support and non-support experienced by women middle managers aspiring for senior management. It is expected that the structure depicted in Figure 1 would provide a guideline for developing attributes and questions in such an exercise. Once the measures are developed, they can be factor analyzed for internal consistency between different categories so that their predictive utility can be further enhanced.

\section{Conclusion}

This paper attempted to propose possible multiple dimensions of personal social support and non-support in relation to career aspirations of women middle managers towards senior management. The dimensions proposed are: attitudes of support senders about women's role, work-family facilitation behaviours, career decision-making support, and support on career development activities. The first dimension, attitudes of support senders about women's role, is proposed to be containing three sub-dimensions: women's role in the family, women's status in the family, and appropriate careers for women. The second dimension, work-family facilitation behaviours, is suggested to encompass three sub-dimensions: sharing domestic roles, managing crossover effect, and partners' consumption of family friendly facilities. The third dimension, career decision making support, is expected to envelop two sub-dimensions: career choice efficacy building behaviour and instrumental support required for career choice decision making. The fourth dimension, support on career development activities, is proposed to contain three sub-dimensions: cultural freedom, resource allocation and relocation flexibility.

The root cause of proposing such dimensions and sub-dimensions was the observations made in relation to limited applicability of widely used measurement instruments of personal social support and non-support to assess a cohort of women in middle management aspiring for senior management. Additionally, it was discussed that theoretical explanations put forth by Bronfrenbrenner (1979), Lent and colleagues (2000), and Bussey and Bandura (1999) in contextual and social cognitive viewpoints reinforces the influences of personal social support 
and non-support in career aspirations of women middle managers. Hence, this paper recommended consideration of suggested dimensions and sub-dimensions in devising a comprehensive measure to capture aforementioned phenomena. It is very much anticipated that such grounded approach would immensely facilitate support-building interventions (Lent \& Brown, 2006) particularly, to raise the status of career aspirations of women middle managers towards senior management. Ultimately, it is expected that such effort would necessarily contribute to close the gender gap in senior management in time to come.

\section{Limitations}

It should be noted that the arguments of this paper is not absence of limitations. It would have been ideal if the authors had resources to broaden the key words and data bases in the literature review. To that extent, there can be more dimensions and sub-dimensions that are not included in this paper. It is also to be noted that the other recommendations and conclusions arrived at this paper inherits this limitation. The paper advocates measurement development procedures adapted by renowned authors in the field. There might be viable alternative measurement development procedures that are worthwhile considering in such a task but not discussed under the purview of this paper.

\section{References}

Anna, A. L., Chandler, G. N., Jansen, E., \& Mero, N. P. (2000). Women business owners in traditional and non-traditional industries. Journal of Business Venturing, 15(3), 279-303. http://dx.doi.org/10.1016/S0883-9026(98)00012-3

Anderson-Gough, F., Grey, C., \& Robson, K. (2005). Helping Them to Forget: The organizational embedding of gender relations in public audit firms. Accounting, Organizations and Society, 30(5), 469-490. http://dx.doi.org/10.1016/j.aos.2004.05.003

Ballentine, A. R. (2000). A Sociological Multiple Life History Study of Three Female Former Community College Presidents in a Southeastern System. Retrieved September 20, 2011, from http://www.asrtfoundation.org/media/dissertations/AI9974571.html

Beaty, D. M., \& Pankake, A. (2001). Primary experiences of female secondary principals. Retrieved October 20, 2011, from http://edtech.connect.msu.edu/searchaera2002/viewproposaltext.asp?propID=1614

Betz, N., \& Fitzgerald, L. (1987). The career psychology of women. Orlando, Florida: Academic Press.

Betz, N. E. (1989). Implications of the null environment hypothesis for women's career development and for counseling psychology. The Counseling Psychologist, 17(1), 136-144. http://dx.doi.org/10.1177/0011000089171008

Bowes, J. M. (2005). Emphasizing the family in work-family research: A review of current research and recommendations for future directions. In S. A. Y. Poelmans (Ed.), International Research on Work and Family (pp. 415-438). Mahwah, NJ: Lawrence Erlbaum Associates.

Bronfenbrenner, U. (1977). Toward an experimental ecology of human development. American Psychologist, 32(7), 513-531. http://dx.doi.org/10.1037/0003-066X.32.7.513

Bronfenbrenner, U. (1979). Contexts of child rearing: Problems and prospects. American Psychologist, 34(10), 844-850. http://dx.doi.org/10.1037/0003-066X.34.10.844

Bussey, K., \& Bandura, A. (1999). Social cognitive theory of gender development and differentiation. Psychological Review, 106(4), 676-713. http://dx.doi.org/10.1037/0033-295X.106.4.676

Byars, A. M., \& Hackett, G. (1999). Applications of social cognitive theory to the career development of women $\begin{array}{llll}\text { of } & \text { color. Applied and Preventive Psychology, } & \text { 7(4), 255-267. }\end{array}$ http://dx.doi.org/10.1016/S0962-1849(98)80029-2

Carter, N. M., \& Silva, C. (2010). The pipelines broken promise. Retrieved August 10, 2011, from http://www.catalyst.org/file/340/pipeline's_broken_promise_final_021710.pdf

Cleveland, J. N., Stockdale, M., \& Murphy, K. R. (2000). Women and men in organizations: Sex and gender issues at work. Mahwah, NJ: Erlbaum.

Connell, R. W. (2002). Gender. Cambridge: Polity Press.

Davidson, M. J., \& Cooper, C. (1992). Shattering the glass ceiling: The woman manager. London: Paul Chapman.

DeVellis, R. F. (2003). Scale development: Theory and applications. Thousand Oaks, CA: Sage Publications. 
Deedar-Ali-Khawaja, R., \& Khan, S. M. (2010). Trends of Surgical Career Selection among Medical Students and Graduates: A Global Perspective. Journal of Surgical Education, 67(4), 237-248. http://dx.doi.org/10.1016/j.jsurg.2010.05.006

Deutsch, F. M., Kokot, A. P., \& Binder, K. S. (2007). College women's plans for different types of egalitarian marriages. Journal of Marriage and Family, 69(4), http://dx.doi.org/10.1111/j.1741-3737.2007.00421.x

Dulk, L. D. (2005). Workplace work-family arrangements: a study and explanatory framework of differences between organizational provisions in different welfare states. In S. A. Y. Poelmans (Ed.), International Research on Work and Family (pp. 415-438). Mahwah, NJ: Lawrence Erlbaum Associates.

Eagly, A. H., Wood, W., \& Diekman, A. B. (2000). Social role theory of sex differences and similarities: A current appraisal. In T. Eckes, \& H. M. Trautner (Eds.), Thedevelopmental social psychology of gender (pp. 123-174). Mahwah, NJ: Lawrence Erlbaum.

Farmer, H. S. (1985). Model of career and achievement motivation for women and men. Journal of Counseling Psychology, 32(3), 363-390. http://dx.doi.org/10.1037/0022-0167.32.3.363

Ferry, T. R., Fouad, N. A., \& Smith, P. L. (2000). The role of family context in a social cognitive model for career-related choice behavior: A math and science perspective. Journal of Vocational Behavior, 57(3), 348-364. http://dx.doi.org/10.1006/jvbe.1999.1743

Flores, L. Y., \& O’Brien, K. M. (2002). The career development of Mexican American adolescent women: A test of social cognitive career theory. Journal of CounselingPsychology, 49(1), 14-27. http://dx.doi.org/10.1037/0022-0167.49.1.14

Forret, M. L., \& Dougherty, T. W. (2004). Networking behaviors and career outcomes: differences for men and women? Journal of Organizational Behavior, 25(3), 419-437. http://dx.doi.org/10.1002/job.253

Fouad, N. A., \& Bingham, R. P. (1995). Career counseling with racial and ethnic minorities. In W. B. Walsh, \& S. H. Osipaw (Eds.), Handbook of vocational psychology: Theory, research, and practice (pp. 331-366). Mahwah, NJ: Lawrence Erlbaum.

Frye, J. (1984). Success and satisfaction: Does it make a difference who you ask? Paper presented at the convention of the American Psychological Association, Toronto.

Gerstel, N., \& Sarkisian, N. (2006). Sociological perspectives on families and work: The import of gender, class, and race. In M. Pitt- Catsouphes, E. E. Kossek, \& S. S., Mahwah (Eds.), The work and family handbook: Multi-disciplinary perspectives and approaches (pp. 237- 266). NJ: Lawrence Erlbaum.

Glick, P., \& Hilt, L. (2000). From combative children to ambivalent adults: The development of gender prejudice. In T. Eckes, \& M. Trautner (Eds.), Developmental Social Psychology of Gender (pp. 243-272). Mahwah, NJ: Erlbaum.

Goldstein, G., Beers S. R., \& Herse, M. (2004). Comprehensive handbook of psychological assessments. New Jercy: John Wiley and sons Inc.

Gordon, J. R., \& Whelan, K. S. (1998). Successful professional women at midlife: how organizations can more effectively understand and respond to the challenges. Academy of Management Executive,12(1), 8-24.

Gordon, J. R., \& Whelan-Berry, K. S. (2004). It Takes Two to Tango: An Empirical Study of Perceived Spousal/Partner Support for Working Women. Women in Management Review, 19(5), $260-273$. http://dx.doi.org/10.1108/09649420410545980

Greenhaus, J. H., \& Parasuraman, S. (1994). Work-family conflict, social support, andwell-being. In M. J. Davidson, \& R. J. Burke (Eds.), Women in Management: Current research issues (pp. 213-229). London: Paul Chapman.

Grzywacz, J. G., \& Marks, N. F. (2000). Reconceptualizing the work-family interface: An ecological perspective on the correlates of positive and negative spillover between nwork and family. Journal of Occupational Health Psychology, 5(1), 111-126. http://dx.doi.org/10.1037/1076-8998.5.1.111

Guillaume, C., \& Pochic, S. (2009). What would you sacrifice? Access to top management and the work-life balance. Gender, Work \& Organization, 16(1), 14-36. http://dx.doi.org/10.1111/j.1468-0432.2007.00354.x 
Hammer, L. B., Bauer, T. N., \& Grandey, A. A. (2003). Work-family conflict and work-related withdrawal $\begin{array}{llll}\text { behaviors. Journal of Business and Psychology, 17(3), 419-436. } & \text {. }\end{array}$ http://dx.doi.org/10.1023/A:1022820609967

Haynes, S. N., Heiby, E. M., \& Herse, M. (2004). Comprehensive handbook of psychological assessments. New Jercy: John Wiley and sons Inc.

Hilsenroth, M. J., Segal, D. L., \& Herse, M. (2004). Comprehensive handbook of psychological assessments. New Jercy: John Wiley and sons Inc.

Hornsby, J. S., Kuratko, D. F., \& Zahra, S. A. (2002). Middle managers' perception of the internal environment for corporate entrepreneurship: assessing a measurement scale. Journal of Business Venturing, 17(3), 253-273. http://dx.doi.org/10.1016/S0883-9026(00)00059-8

House, J. S., \& Kahn, R. L. (1985). Measures and concepts of social support. In S. ohen, \& S. L. Syme (Eds.), Social support and health (pp. 83-108). Orlando, FL: Academic Press.

International Labour Organization. (2010). Women in labour markets: Measuring progress and identifying challenges. Retrieved July 12, 2011, from http://www.ifrro.org

Kim, J., Ling, C. (2001). Work-family conflict of women entrepreneurs in Singapore. Women in Management Review, 16(5), 204-221. http://dx.doi.org/10.1108/09649420110395692

Larwood, L., \& Gutek, B. A. (1987). Working towards a theory of women's career development. In B. A. Gutek \& L. Larwood (Eds.), Women's careerdevelopment (pp. 170-183). Newbury Park, CA: Sage.

Lawrence, J., Poole, P., \& Diener, S. (2003). Critical factors in career decision making for women medical graduates. Medical Education, 37(4), 319-327. http://dx.doi.org/10.1046/j.1365-2923.2003.01476.x

Lease, S. H. (2006). Factors predictive of the range of occupations considered by African American juniors and seniors in high school. Journal of Career Development, 32(4), 333-350. http://dx.doi.org/10.1177/0894845305283003

Lent R. W., Brown, S. D., \& Hackett, G. (2002). Social Cognitive Career theory. In D. Brown, L. Brooks, \& Associates (Eds.), Career choice and development (pp. 255-311). Sanfransisco: Jossey-Bass.

Lent, R. W., Brown, D., \& Hackett, G. (2000). Contextual Supports and Barriers to career choice: A Social


http://dx.doi.org/10.1037/0022-0167.47.1.36

Lent, R. W., Brown, S. D., Sheu, H. B., Schmidt, J., Brenner, B. R., Gloster, C. S., \& Treistman, D. (2005). Social Cognitive Predictors of Academic Interests and Goals in Engineering: Utility for Women and Students at Historically Black Universities. Journal of Counseling Psychology, 52(1), 84-92. http://dx.doi.org/10.1037/0022-0167.52.1.84

Lent, R. W., Brown, S. D., Schmidt, J., Brenner, B., Lyons, H., \& Treistman, D. (2003b). Relation of contextual supports and barriers to choice behaviour in engineering majors: test of alternative social cognitive models. Journal of Counseling Psychology, 50(4), 458-465. http://dx.doi.org/10.1037/0022-0167.50.4.458

Lent, R. W., Lopez J., A. M., Lopez, F. G., \& Sheu, H. B. (2008) . Social cognitive career theory and the prediction of interests and choice goals in the computing disciplines. Journal of Vocational Behavior, 73(1), 52-62. http://dx.doi.org/10.1016/j.jvb.2008.01.002

Lent, R. W., Singley, D., Sheu, H. B., Schmidt, J. A., \& Schmidt, L. C. (2007). Relation of social-cognitive factors to academic satisfaction in engineering students. Journal of Career Assessment, 15(1), 87-97. http://dx.doi.org/10.1177/1069072706294518

Lent, R., \& Brown, S. (2006). On conceptualizing and assessing social cognitive constructs in career research: A measurement guide. Journal of Career Assessment, 14(1), 12-35. http://dx.doi.org/10.1177/1069072705281364

Lent, R., \& Brown, S. Hackett, G. (1994). Toward a unifying social cognitive theory of career and academic interest, choice, and performance. Journal of Vocational Behavior, 45(1), 79-122. http://dx.doi.org/10.1006/jvbe.1994.1027

Lent, R., Brown, S., Brenner, B., Chopra, S., Davis, T., Talleyrand, R., \& Suthakaran, V. (2001). The role of contextual supports and barriers in the choice of math/science educational options: A test of social cognitive 
$\begin{array}{lllll}\text { hypotheses. Journal of } & \text { Counseling }\end{array}$ http://dx.doi.org/10.1037/0022-0167.48.4.474

Lent, R., Brown, S., Nota, L., \& Soresi, S. (2003a). Testing social cognitive interest and choice hypotheses across Holland types in Italian high school students. Journal of Vocational Behavior, 62(1), 101-118. http://dx.doi.org/10.1016/S0001-8791(02)00057-X

Levine, R. B., Lin, F., Kern, D. E., Wright, S. M., \& Carrese, J. (2011). Stories from early-career women physicians who have left academic medicine: aqualitative study at a single institution. Academic Medicine, 86(6), 752. http://dx.doi.org/10.1097/ACM.0b013e318217e83b

Levinson, D. (1996). The Seasons of a Woman's Life. New York: Knopf.

Levinson, D., Darrow, C., Klein, E., Levinson, M., \& McKee, B. (1978). The Seasons of a Man'sLife. New York : Knopf.

Linehan, M., \& Walsh, J. S. (1999). Recruiting and developing female managers for international assignments. Journal of Management Development, 18(6), 521-530. http://dx.doi.org/10.1108/02621719910279608

Lo, S. (2003). Perceptions of work-family conflict among married female professionals in Hong Kong. Personal Review, 32(3), 376-390. http://dx.doi.org/10.1108/00483480310467679

Mainiero, L. A., \& Sullivan, S. E. (2005). Kaleidoscope careers: An alternate explanation for the "opt-out"

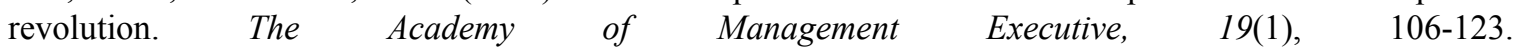
http://dx.doi.org/10.5465/AME.2005.15841962

Marcinkus W. C., Whelan-Berry K. S., \& Gordon J. R. (2007). The Relationship of Social Support to the WorkFamily Balance and Work Outcomes of midlife Women. Women in Management Review, 22(2), 86-111. http://dx.doi.org/10.1108/09649420710732060

Markham, W. T., \& Pleck, J. H. (1986). Sex and willingness to move for occupational advancement: some national sample results. Sociological Quarterly, 27(1), 121-143. http://dx.doi.org/10.1111/j.1533-8525.1986.tb00253.x

Maxwell, G., \& Ogden, S. M, (2006). Career Development of Female Managers in Retailing: Inhibitors and Enablers. Journal of Retail and Consumer Services, 13, 111-120. http://dx.doi.org/10.1016/j.jretconser.2005.08.010

McElwain, A., Korabik, K., \& Rosin, H. M. (2005). An examination of gender differences in work-family conflict. Canadian Journal of Behavioural Science, 37(4), 269-284.

McGowan, S. (2007). Age and aspirations: How female managers view their careers. Retrieved September 3, 2011, from http://ca.hudson.com/documents/women-managers-age-ambition-study.pdf

Michelle Streich, Wendy J. Casper, \& Amy Nicole Salvaggio. (2008). Examining couple agreement about work-family conflict. Journal of Managerial Psychology, 23(3), 252-272. http://dx.doi.org/10.1108/02683940810861374

Murtagh, N., Lopes, P., \& Lyons, E. (2007). What makes a career barrier a barrier? Industrial and Commercial Training, 39(6), 332-339. http://dx.doi.org/10.1108/00197850710816818

O'Brien, K. (1996). The influence of psychological separation and parental attachment on the career development of adolescent women. Journal of Vocational Behavior, 48(3), 257-274. http://dx.doi.org/10.1006/jvbe.1996.0024

Omar, A., \& Davidson, M. J. (2001). Women in management: a comparative cross-cultural overview. International Journal of Cross Cultural Management, $8(3), \quad 35-67$. http://dx.doi.org/10.1108/13527600110797272

Otto, L. B. (2000). Youth perspectives on parental career influence. Journal of Career Development, 27(2), 111. http://dx.doi.org/10.1177/089484530002700205

Plake, B.S., Impara, J. C., \& Spies, R. A. (2003). The mental measurement year book. Buros Institute of mental measurements, Lincoln: University of Nebrasca.

Perna, L. W. (2001). The relationship between family responsibilities and employment status among college and university faculty. The Journal of Higher Education, 72(5), 584-611. http://dx.doi.org/10.2307/2672882

Reyes, O., Kobus, K., \& Gillock, K. (1999). Career aspirations of urban, Mexican American adolescent females. Hispanic Journal of Behavioral Sciences, 21(3), 366-382. http://dx.doi.org/10.1177/07399866399213010 
Rönsen, M., \& Sundström, M. (1996). Maternal Employment in Scandinavia: A Comparison of the After-birth Employment Activity of Norwegian and Swedish Women. Journal of Population Economics, 9(3), $267-285$. http://dx.doi.org/10.1007/BF00176688

Rowe, H. A. H. (2003). The work potential profile. In B. S. Plake, J. C. Impara, \& R. A. Spies (Eds.), The mental measurement year book (pp. 1028-1031). Buros Institute of mental measurements, Lincoln: University of Nebrasca.

Russell, J., \& Rush, M. (1987). A comparative study of age-related variation in women's views of a career in $\begin{array}{lllll}\text { management. } & \text { Journal } & \text { Bochational } 294 .\end{array}$ http://dx.doi.org/10.1016/0001-8791(87)90006-6

Schein, V. E. (2001). A global look at psychological barriers to women's progress in management. Journal of Social Issues, 57(4), 675-688. http://dx.doi.org/10.1111/0022-4537.00235

Schulz, R., \& Rau, M. T. (1985). Social support through the life course. In S. Cohen, \& L. Syme (Eds.), Social Support and Health (pp. 129-149). New York: Academic Press.

Sellers, S. L., \& Hunter, A. G. (2005). Private pain, public choices: Influence of problems in the family of origin on career choices among a cohort of MSW students. Social work education, 24(8), 869-881. http://dx.doi.org/10.1080/02615470500342223

Shaffer, M. A., Francesco, A. M., Joplin, J. R. W., \& Lau, T. (2005). Easing the pain: A cross-cultural study of support resources and their influence on work-family conflict. In S. Poelmans (Ed.), Work and Family: An International Research Perspective (pp. 319-340). Mahwah, NJ: Erlbaum.

Sheu, H. B., Lent, R. W., Brown, S. D., Miller, M. J., Hennessy, K. D., \& Duffy, R. D. (2010). Testing the choice model of social cognitive career theory across Holland themes: A meta-analytic path analysis. Journal of Vocational Behavior, 76(2), 252-264. http://dx.doi.org/10.1016/j.jvb.2009.10.015

Streich, M., Casper, W. J., \& Salvaggio, A. N. (2008). Examining couple agreement about work-family conflict. Journal of Managerial Psychology, 23(3), 252-272. http://dx.doi.org/10.1108/02683940810861374

Sutton, K. L. \& Noe, R. A. (2005). Family friendly programmes and work-life integration. More myth than magic? In E. E. Kossek, \& S. J. Lambert (Eds.), Work and life integration: organizational, cultural and individual perspectives (pp. 151-170). Mahwah, NJ: Lawrence Erlbaum Associates.

Swanson, J., \& Woitke, M. (1997). Theory into practice in career assessment for women: Assessment and interventions regarding perceived career barriers. Journal of Career Assessment, 5(4), 443-462. http://dx.doi.org/10.1177/106907279700500405

Swanson, J. L., \& Tokar, D. M. (1991b). Development and initial validation of the Career Barreirs Inventory. Journal of Vocational Behavior, 39, 344-361. http://dx.doi.org/10.1016/0001-8791(91)90043-L

Swanson, J. L., \& Tokar, D. M. (1991a). College students' perceptions of barriers to career development. Journal of Vocational Behavior, 38(1), 92-106. http://dx.doi.org/10.1016/0001-8791(91)90020-

Swanson, J., K., Daniels, K. K., \& Tokar, D. M. (1996). Assessing perceptions of career-related barriers: The Career Barriers Inventory. Journal of Career Assessment, 4(2), $219-244$. http://dx.doi.org/10.1177/106907279600400207

Thomas, J. C., \& Herse, M. (2004). Comprehensive handbook of psychological assessments. New Jercy: John Wiley and sons Inc.

Vondracek, F. W., Lerner, R. M., \& Schulenberg, J. E. (1986). Career development: A life-span developmental approach. London: Erlbaum Associates.

Wallen, J. (2002). Balancing Work and Family: The Role of the Workplace. Bostan: Allyn and Bacon.

Wentling, R. M. (1996). Women in middle management: Their career development and aspirations. Business Horizons, 35(1), 47-54. http://dx.doi.org/10.1016/0007-6813(92)90115-P

Wentling, R. M. (2003). The career development and aspirations of women in middle management-revisited. Women in management review, 18(6), 311-324. http://dx.doi.org/10.1108/09649420310491486

Westman, W. (2005). Cross-cultural differences in cross-over effect. In S. A. Y. Poelmans (Ed.), International Research on Work and Family (pp. 241-260). Mahwah, NJ: Lawrence Erlbaum Associates. 
Wharton, A. S. (2006). Understanding diversity of work in the 21 st century and its impacton the work-family area of study. In M. Pitt-Catsouphes, E. E. Kossek, \& S. S., Mahwah (Eds.), The work and family handbook: Multi-disciplinary perspectives and approaches (pp.17-40). NJ: Lawrence Erlbaum.

Whelan-Berry, K. S., \& Gordon, J. R. (2000). Strengthening Human Resource Strategies: Insights from the Experiences of Midcareer Professional Women. Human Resource Planning, 23(1), 26-37.

Xian, H. P., \& Woodhams, C. (2008). Managing careers: Experiences of successful women in the Chinese IT industry. Gender in Management: An International Journal, 23(6), 409-425. http://dx.doi.org/10.1108/17542410810897535

Young, M. D., \& McLeod, S. (2001). Flukes, opportunities, and planned interventions: Factors affecting women's decisions to become school administrators. Educational Administration Quarterly, 37(4), 462-502. 